\title{
Ortaokul Matematik Ders Kitaplarının Matematik Öğretmenleri Tarafından Değerlendirilmesi
}

\author{
Ebru Korkmaz $^{1^{*}}$, Tayfun Tutak ${ }^{2 *}$, Aziz İlhan ${ }^{3}$ \\ ${ }^{1}$ Muş Alparslan Üniversitesi, Eğitim Fakültesi, Matematik Eğitim Bölümü, Muş, Türkiye (ORCID: 0000-0001-6250-3293) \\ 2 Fırat Üniversitesi, Eğitim Fakültesi, Matematik Eğitimi Bölümü, Elazı̆ğ, Türkiye (ORCID: 0000-0002-0277-6377) \\ ${ }^{3}$ Munzur Üniversitesi, Çemişgezek MYO, Matematik Bölümü, Tunceli, Türkiye (ORCID: 0000-0001-7049-5756)
}

(İlk Geliş Tarihi 5 Ocak 2020 ve Kabul Tarihi 13 Şubat 2020)

(DOI: 10.31590/ejosat.667689)

\begin{abstract}
ATIF/REFERENCE: Korkmaz, E., Tutak, T., İlhan, A., (2020). Ortaokul Matematik Ders Kitaplarının Matematik Öğretmenleri
\end{abstract} Tarafından Değerlendirilmesi. Avrupa Bilim ve Teknoloji Dergisi, (18), 118-128.

$\ddot{\mathbf{O} z}$

$\mathrm{Bu}$ araştırmanın amacı, ortaokul matematik ders kitaplarını öğretmen görüşlerine göre değerlendirmektir. $\mathrm{Bu}$ genel amaç doğrultusunda çalışmada, ders kitaplarının Liselere Giriş Sınavı (LGS)'ye uygunluğu, öğretim sürecinde aktif kullanımı, okullarda uygulanan eğitim müfredatına uygunluğu ve eğitim faaliyetlerindeki ekstra kaynak ihtiyacı da araştırılmıştır. Dolayısıyla araştırmada durum çalışması yapılmıştır. Veriler analiz edilirken içerik analizi yöntemi tercih edilmiş, frekanslara göre kodlar, kodlara göre kategoriler ve kategorilere göre frekanslar oluşturulmuştur. Araştırmanın örneklemini, Türkiye'nin Doğu Anadolu bölgesinde bulunan orta büyüklükteki bir ildeki yedi farklı ortaokulda görev yapan yirmi dört ortaokul matematik öğretmeni oluşturmaktadır. Örneklem seçiminde öncelikle okullar tespit edilmiş, daha sonra bu okullardan hizmet deneyimi en az 5 yıl olan öğretmenler tercih edilmiştir. Bu örneklemi oluşturan öğretmenler gönüllüllük esasına göre belirlenmiştir. Ayrıca örneklem belirlenirken zaman ve işgücü koşulları göz önünde bulundurulmuştur. Dolayısıyla araştırma örneklemi seçilirken uygun örnekleme yöntemi tercih edilmiştir. Çalışmada veri toplama aracı olarak araştırmacılar tarafindan geliştirilmiş beş adet açı uçlu sorudan oluşan yapılandırılmış görüşme formu kullanılmıştır. Bu form geliştirilirken üç adet matematik eğitimi alanında uzman akademisyenin görüşü alınmıştır. Formun güvenirliği için KAPPA değeri 0,922 olarak hesaplanmış, güvenilir olduğuna karar verilmiştir. Araştırmada elde edilen bulgulara göre öğretmenlerin büyük çoğunluğu ders kitaplarının LGS'ye uygun olmadığını düşünmektedirler. Bir kısmı ise mevcut kitapların birtakım özellikleri gözden geçirilerek geliştirilebileceği düşüncesindedir. Ayrıca öğretmenlerin büyük çoğunluğu ders kitaplarını derste aktif bir şekilde kullanmayı tercih etmezken, ders kitaplarını daha çok öğrencilere ödev vermek amacıyla kullanmaktadır. Bununla birlikte öğretmenlerin ders kitaplarının yetersiz olduğunu düşündükleri için öğrencileri ek kaynak kitaplara yönlendirdikleri tespit edilmiştir. Araştırmada elde edilen bulgular çerçevesinde ileride bu alanda çalışmak isteyen araştırmacılara ortaokul matematik ders kitaplarının kullanımına ve geliştirilmesine ilişkin birtakım önerilerde bulunulmuştur.

(Minimum 250 - Maksimum 400 kelime ve içeriğinde amaç, materyal-metot, bulgular ve sonuç kısımlarını içerecek şekilde yazılmalıdır.)

Anahtar Kelimeler: Ortaokul Matematik Dersi, Ders Kitapları, LGS Sınavı, Değerlendirme, Matematik Eğitimi.

\section{Evaluation of Secondary School Mathematics Textbooks by Mathematics Teachers}

\begin{abstract}
The aim of this study is to evaluate secondary school mathematics textbooks according to teachers' opinions. In line with this general purpose, the study examined the appropriateness of the textbooks to the High School Entrance Examination (HSEE), its active use in
\end{abstract}

\footnotetext{
* Sorumlu Yazar: Fırat Üniversitesi, Eğitim Fakültesi, Matematik Eğitimi Bölümü, Elazı̆̆, Türkiye, ORCID: 0000-0002-0277-6377, tayfuntutak@firat.edu.tr
} 
the teaching process, its appropriateness to the education system implemented in schools, and the need for extra resources in educational activities. Therefore, case study was conducted in the study. While analyzing the data, content analysis method was preferred, codes according to frequencies, categories according to codes and frequencies according to catehores were created. The sample of the study, Turkey's role in seven different secondary schools in a mid-sized city located in Eastern Anatolia is engaged twenty-four secondary school math teacher. Firstly, schools were identified in the sample selection, and then teachers with at least 5 years of service experience were chosen from these schools. Teachers of this sample were determined on a voluntary basis. In addition, time and labor conditions were taken into consideration while determining the sample. Therefore, appropriate sampling method was preferred when selecting the research sample. In the study, a structured interview form consisting of five open-ended questions developed by the researchers was used as data collection tool. In the development of this form, the views of three academicians specialized in mathematics education were taken. For reliability of the form, the KAPPA value was calculated as 0.922 and it was decided that it was reliable. According to the findings of the research, the majority of teachers think that textbooks are not HSEE compliant. Some think that the features of the existing books can be revised and improved. In addition, while the majority of teachers do not prefer to use textbooks actively in class, they use textbooks mostly to give homework to students. However, it was found that teachers direct students to additional source books because they think that their textbooks are insufficient. Within the framework of the findings obtained in the research, some suggestions were made to the researchers who want to work in this field in the future about the use and development of secondary school mathematics textbooks.

(Minimum 250 - Maximum of 400 words and content should be written in a way to include material, method, findings and results.)

Keywords: Secondary School Maths Lesson, Course Books, HSE Exam, Math Education.

\section{Giriş}

Türk Eğitim Sistemindeki ve dünya çapındaki hızlı gelişmeler günümüz eğitim anlayışını da hızla değiştirmektedir. Bu doğrultuda Türk eğitim sistemi de sürekli değişime uğramaktadır. Değişimler ve yenilikler doğrultusunda öğrencilere kazandırılacak bilgi ve becerilerin çağa uygun düzenlemeler ile programlanması gerekmektedir. Bu konuda MEB müfredatı da evrensel eğitim anlayışına ve çağın gereksinimine uygun olarak hazırlamalıdır. Uygulanacak müfredatın sistemin bir parçası olan sınavların içeriği ile uyuşması, öğretmenler tarafından benimsenmesi ve bu konuda öğretmenleri destekleyici niteliklerde olması gerekmektedir (MEB, 1997). Ders kitabının, eğitim ve öğretim açısından kullanışlı olması, tüm öğrencilerin kolaylıkla ulaşabilmesi, öğretmenler tarafından sıkça tercih edilen, öğrencilerin istediği zaman ulaşabileceği, hem ders içinde hem dışında başvurulabilen bir eğitim aracı olması beklenmektedir (Göze, 1999). Ders kitapları genellikle gelişen ve gelişmekte olan ülkelerde kullanılan önemli eğitim araçlarından biridir (Semerci, 2004, s. 49).

Ders kitapları, eğitim sistemlerinin ve programlarının amacını temsil eden yazılı ve basılı eğitim-öğretim aracıdır. Ülkemizde ders programı hazırlanırken önceliğin dersin içeriğine verilmesi doğru fakat yetersiz olmuştur (Delice, Aydın, Kardeş, 2009, s. 76). Türkiye' de ders kitapları sık kullanılan eğitim araçlarındandır. Ders kitapları öğrencilere derse önceden hazırlanma firsatı ve sonradan dersi tekrar etme firsatı tanımaktadır. Ayrıca ortaokul 8. sınıf öğrencilerinin yeni sınav sistemi olan LGS için ders kitaplarının yeterli olması ve bir ek kaynağa başvurma ihtiyacını hissettirmemesi gerekmektedir. Matematik derslerindeki başarısızlığın temel nedenlerinden birisi ortaokul matematik ders kitaplarının iyi hazırlanmış olmamasından kaynaklanmaktadır. Ders kitapları günlük hayat ile bağdaşmaması, ifadelerin açık ve anlaşılır olmaması, yaş grubuna ait bireylerin dikkatini çekecek içerik ve uygulamalar bulunmamasından dolayı verimi düşürebilmektedir (Dane, Doğar, Balkı, 2004, s. 3). LGS'ye hazırlanan öğrenciler ders kitaplarının yetersiz olmasından kaynaklanan nedenlerle, öğretmenler tarafından ek kaynaklara yönlendirilebilmektedir. Ders kitaplarının yeterince uygulamaya yer vermemesi, soru çeşitliliğinin az olması, LGS'de sorulan sorular ile yeterince uygunluk göstermemesi gibi nedenlerden dolayı tercih edilmeme ya da ek kaynağa ihtiyaç duyma gereksinimi ortaya çıkabilmektedir.

Ders kitaplarıyla ilgili yapılmış araştırmalar dünya genelinde ders kitapları oluşturulurken bir kriterin olmadığını göstermektedir. Ortak bir kriterin olmamasının nedeni, her toplumun kendine özgü sosyal yapısının olması ve kültürel ihtiyaçlarının farklı olmasından kaynaklanmaktadır. Eğitim ihtiyaçları farklı olan ülkelerin eğitim sistemleri de farklılık göstermektedir. Ülkeler kendi eğitim sistemlerine göre ders kitapları oluşturmaktadır. Dolayısıyla ders kitaplarının içeriği ülkenin dinamikleri olan sosyal yapı, kültürel yapı ve ihtiyaçlara göre öğrencilerin dikkatini çekecek şekilde harmanlanıp sunulmalıdır. Ders kitapları hazırlanırken teknik ve görsel, içerik, dil ve anlatım bakımından iyi hazırlanmalıdır. Hazırlanan ders kitabının dili yaş grubuna uygun olarak yalın ve sade olmalıdır. Ders kitabına ilişkin yapılan eleştirilerden birisi de kitapların öğrenciler için değil de öğretmenler için yazılmış olmasıdır (Dane vd. 2004, s.3). Ortaokulda sürekli değişen sınav sistemlerinden kaynaklanan, ders kitaplarının tek başına yetersiz kalması öğrencilerin ders kitaplarını verimli kullanmasını engellemektedir. Sınav merkezli eğitim anlayışından dolayı öğrenciler ders kitaplarını ilk kaynak olarak görmemektedirler. Ders kitapları daha çok okuldaki müfredata uygun kazanımları kapsarken, LGS sınavlarında, ders kitaplarındaki kazanımlar ve soru çeşitleri eksik kalabilmektedir. Dolayısıyla ders kitapları sınava uygunluk göstermelidir. Sınav merkezli eğitimden dolayı öğrenciler öğrenmeyi kalıcı öğrenmekten çok, bilgiyi yapılandırmadan hazır olarak almayı tercih edebilmektedir. $\mathrm{Bu}$ da ders kitaplarının öğretmen ve öğrencilerin tercih alanından çıkmasına neden olabilmektedir (Aydoğdu İskenderoğlu, Baki, 2011, s. 292).

Matematik öğretiminde ders kitabı içeriğinin zengin olması matematik öğretiminde tek başına yeterli değildir. İçeriğin yanında ders kitaplarında günlük yaşamdan örnekleri barındırması, görsel ifadelerin sıkça kullanılması, dilin anlaşılır sade olması ö ğrencilerin dikkatini çekici kılmaktadır. Ortaokul çağındaki öğrencilerin soyut düşünme becerilerinin gelişmemiş olmasından dolayı ders kitaplarında modelleme kullanılmalı ve soyut düşünme becerilerinin gelişimi açısından destekleyici etkinlikler içermelidir. Ders kitaplarının öğrenciye rehberlik edecek şekilde açık olmalıdır. Öğrenci ilgisini çekecek içeriğe sahip olmalıdır (Güven, 2010, s. 86). 
Okullarda öğretilen matematiğin bir amacı, toplum içinde matematiğin kullanılmasını sağlamak ve hayatı kolaylaştırmaktır. Böylece toplumda ihtiyaç duyulan alanlara istihdamı sağlayabilmek için matematik öğretimi değer kazanmıştır. Akademik anlamda matematikçiler küçük yaşlardan yetiştirilerek matematiğin gelişimi ve devamı amaçlanmaktadır. Dolayısıyla ortaokul kademesinde öğrencilerin edineceği her bilgi toplum için önemli bir kazanım olarak değerlendirilmektedir. Yetiştirilen bireylerin toplumun ihtiyaçlarını karşılayabilmeleri için de iyi bir eğitimden geçmeleri gerekmektedir. Dolayısıyla eğitim ve eğitim araçlarının iyi hazırlanması, öğrencilere iyi bir şekilde sunulması gerekmektedir. Ders kitapları da bu konu da önemli bir yere sahiptir (Dane vd. 2004, s. 3). Literatürdeki bu çalışmalar ders kitaplarının öğrenme süreçleri için ne kadar önemli olduğunu göstermektedir. Ders kitaplarının güncellenmesi için farklı kaynaklardan dönütler alınmaktadır. Bu kitapların birer kullanıcısı ve yol göstericisi olan öğretmenler açısından da ders kitapları önemli görülmektedir. Dolayısıyla araştırmada ortaokul matematik öğretmenleri tarafindan uyguladıkları ders kitapları değerlendirilmiş, bu konudaki görüşleri detaylı bir şekilde analiz edilmiştir. Bu konudaki öğretmen görüşlerinin detaylı bir şekilde araştırılmasının ileride yazılacak ortaokul matematik kitaplarına yol göstereceği öngörülmektedir.

\section{Çalışmanın amacı:}

$\mathrm{Bu}$ çalı̧̧manın amacı, MEB tarafindan dağıtılan ders kitaplarının yeni sınav sistemine olan uygunluğunu öğretmen görüşleri doğrultusunda değerlendirmektir. Bu genel amaç doğrultusunda şu alt problemlere cevap aranmıştır;

Ortaokul matematik öğretmenlerinin;

1. MEB'in dağıttığı ders kitaplarının LGS'ye uygunluğu hakkındaki görüşleri nasıldır?

2. MEB'in dağıttığı ders kitaplarının aktif kullanımı hakkındaki görüşleri nasıldır?

3. Derste ekstra kaynak kullanımı hakkındaki görüşleri nasıldır?

4. MEB'in dağıttığı ders kitaplarının eğitim müfredatına uygunluğu hakkındaki görüşleri nasıldır?

\section{Çalışma Örneklemi}

Araştırmanın örneklemini, Türkiye'nin Doğu Anadolu bölgesinde bulunan bir ildeki 7 farklı ortaokulda görev yapan 24 ortaokul matematik öğretmeni oluşturmaktadır. Bu örneklemi oluşturan 24 öğretmen gönüllülük esasına göre seçilmiştir. Örneklem seçiminde öncelikle okullar tespit edilmiş, daha sonra bu okullardan hizmet deneyimi en az 5 yıl olan öğretmenler belirlenmiştir. Bu öğretmenler 5. 6. 7. ve 8. sınıf matematik derslerine girmektedir. Ayrıca örneklem belirlenirken zaman ve işgücü koşulları göz önünde bulundurulmuştur. Dolayısıyla örneklem seçilirken uygun örnekleme yöntemi tercih edilmiştir. Uygun örnekleme yöntemi; zaman, para ve işgücü açısından var olan sınırlılıklar nedeniyle örneklemin kolay ulaşılabilir ve uygulama yapılabilir birimlerden seçilmesidir (Büyüköztürk, Çakmak, Akgün, Karadeniz \& Demirel, 2016)..

\section{Materyal ve Metot}

\subsection{Yöntem}

Araştırmanın nitel veriler barındırması sebebiyle bu çalışmada durum çalışması yapılmıştır. Durum çalışması, sınırlı bir sistemin nasıl işlediği ve çalıştı̆̆ hakkında sistematik bilgi toplamak için çoklu veri toplama kullanılarak o sistemin derinlemesine incelenmesini içeren metodolojik bir yaklaşımdır (Chmiliar, 2010). Merriam (2013) ise durum çalışmasını sınırlı bir sistemin derinlemesine betimlenmesi ve incelenmesi olarak tanımlamaktadır. Öte yandan, Creswell (2007)'e göre durum çalışması; araştırmacının zaman içerisinde sınırlandırılmış bir veya birkaç durumu çoklu kaynakları içeren veri toplama araçları (gözlemler, görüşmeler, görsel-işitseller, dokümanlar, raporlar) ile derinlemesine incelediği, durumların ve duruma bağlı temaların tanımlandığı nitel bir araştırma yaklaşımı şeklinde tanımlamaktadır. Davey (2009)'e göre durum çalışması elde edilen sonuçlarla olayın neden o şekilde oluştuğu ve gelecek çalışmalarda nelere odaklanılması gerektiğini ortaya koymaktadır.

\subsection{Veri Toplama Aracı}

Çalışmada veri toplama aracı olarak araştırmacılar tarafindan geliştirilmiş beş adet açık uçlu sorudan oluşan yapılandırılmış görüşme formu kullanılmıştır. Bu form geliştirilirken üç adet matematik eğitimi alanında uzman akademisyenin görüşü alınmıştır. Öncelikle 7 sorudan oluşan taslak form hazırlanmıştır. Uzman görüşü sonrası bir soru taslak formdan çıkarılmış, araştırma örnekleminden farklı 12 ortaokul matematik öğretmenine ön uygulama yapılmıştır. Bu uygulama neticesinde bir adet sorunun araştırma kapsamı için uygun olmadığına karar verilmiş ve formdan çıkarılmıştır. Ayrıca uzmanlardan formu tekrar içerik ve kapsam açısından incelemeleri ve tekrardan her bir soru için uygun (3), kısmen uygun (2) ve uygun değil (1) şeklinde puanlama yapmaları istenmiş̧ir. $\mathrm{Bu}$ puanlama neticesinde formun güvenirliği için KAPPA değeri 0,922 olarak hesaplanmış, güvenilir olduğuna karar verilmiştir. Böylece formun geçerliliği ve güvenirliği sağlanmıştır.

\subsection{Verilerin Analizi}

Araştırma nitel veriler barındıran durum çalışması türündedir. Dolayısıyla çalışma verileri yapılandırılmış görüşme formuyla toplanmıştır. Elde edilen verilen öncelikle Microsoft Office Excel programı yardımıyla dijital ortama geçirilmiş, daha sonra NVIVO programıyla içerik analizi yapılmışıı. Böylece veriler analiz edilirken frekanslara göre kodlar, kodlara göre kategoriler ve kategorilere göre temalar oluşturulmuştur. Bu temalar, frekanslar, kodlar ve kategoriler oluşturulurken her üç araştırmacı birbirinden bağımsız bir şekilde istatistiksel işlemi yürütmüş, daha sonra elde edilen bulgular karşılaştırılmıştır. Frekanslar arası farklılıklar analiz edildikten 
sonra bir adet frekans ve iki adet kod ile kategori arasında mütabakata varılmış, bu doğrultuda analiz süreci tamamlanmıştır. Daha sonra elde edilen bulgular tablolaştırılarak okuyucuya sunulmuştur.

\section{Bulgular}

Çalışmanın bu bölümünde ortaokul matematik ders kitaplarının öğretmen görüşlerine göre değerlendirilmesine ilişkin bulgulara yer verilmiş̧tir. Ayrıca, ders kitaplarının Liselere Giriş Sınavı (LGS)'ye uygunluğu, öğretim sürecinde aktif kullanımı, okullarda uygulanan eğitim müfredatına uygunluğu ve eğitim faaliyetlerindeki ekstra kaynak ihtiyacına ilişkin bulgulara da yer verilmiş̧ir. Araştırmada ilk olarak ortaokul matematik öğretmenlerine MEB'in dağıttığı ders kitaplarının LGS'ye uygunluğu sorulmuş̧ur. Bu soruya verilen yanttlardan elde edilen frekans, yüzde, kod, kategori ve temalara ilişkin bulgular Tablo 1'de verilmiştir.

Tablo 1. MEB'in dağıtttı̆g ders kitaplarının LGS' ye uygunluğu

\begin{tabular}{ccccc}
\hline Tema & Kategori & Kod & Frekans & $\%$ \\
\hline \multirow{2}{*}{ Ders Kitaplarının } & \multirow{2}{*}{ Pozitif } & Kısmen Uygun & 4 & $\mathbf{1 6 , 6 6 6}$ \\
LGS' ye & & Uygun & 3 & $\mathbf{1 2 , 5 0 0}$ \\
\cline { 3 - 5 } Uygunluğu & \multirow{2}{*}{ Negatif } & LGS Düzeyi ile Uyumsuz & $\mathbf{9}$ & $\mathbf{3 7 , 5 0 0}$ \\
& & İçerik Sorunlu & $\mathbf{6}$ & $\mathbf{2 5 , 0 0 0}$ \\
& & Anlaşıllabilirliği Düşük & $\mathbf{2}$ & $\mathbf{8 , 3 3 3}$ \\
\hline
\end{tabular}

Tablo 1'de ders kitaplarının LGS'ye uygunluğu teması altında pozitif ve negatif olacak şeklinde 2 kategori oluştuğu görülmektedir. Pozitif kategori altında matematik öğretmenlerinin yaklaşık \%17'si ( $\mathrm{f}=4)$ ders kitaplarını kısmen uygun bulurken, \%13’ü (f=3) uygun bulmaktadır. Negatif kategori altında ise matematik öğretmenlerinin yaklaşık \%38'i (f=9) ders kitaplarını LGS sorularının düzeyi ile uyumsuz, $\% 25$ 'i $(\mathrm{f}=6)$ içeriği sorunlu, $\% 8$ 'i $(\mathrm{f}=2)$ anlaşılabilirliği düşük görmektedir. Elde edilen bulgulara ilişkin örnek öğretmen görüşleri şöyledir;

Ö5. Ders kitapları içerik, kazanım ve soru bakımından LGS sınav sistemi için uygundur.

Ö10. Uygun değildir. Çünkü LGS' de daha çok yorum ve bilgi ağırlık iken ders kitabı direkt bilgiye dayalıdır ve kısa sorular çoğunluktadır.

Ö17. Ders kitabında bilgi ve kavrama düzeyinde içerik ve sorular var. Yeni sinav sistemi ise mantık, muhakeme ve analitik beceri isteyen sorulardır. Bu nedenle uygun değildir.

Ö19. Önceki yıllar dağıtılan ders kitaplarına oranla uygunluğunun arttırıldĭ̆ı söylenebilir. Uygun olması için üzerinde çalışılması gerektiği kanaatindeyim.

Ö22. Uygun değildir. Kitap anlaşılması zor örneklerden ve deneylerden oluşmaktadır.

Araştırmada ikinci olarak ortaokul matematik öğretmenlerine dağıtılan ders kitaplarının derste aktif olarak kullanılması sorulmuştur. Bu soruya verilen yanıtlardan elde edilen frekans, yüzde, kod, kategori ve temalara ilişkin bulgular Tablo 2'de verilmiştir.

Tablo 2. Dağıttılan ders kitaplarının derste aktif olarak kullanılması

\begin{tabular}{|c|c|c|c|c|}
\hline Tema & Kategori & Kod & Frekans & $\%$ \\
\hline \multirow{3}{*}{$\begin{array}{l}\text { Ders Kitabının } \\
\text { Aktif Kullanımı }\end{array}$} & \multirow{2}{*}{ Pozitif } & Konu İçeriği, Müfredat ve Kazanımlar & 9 & 37,500 \\
\hline & & Alıștırmalar ve Sorular & 3 & 12,500 \\
\hline & Negatif & $\begin{array}{c}\text { Konu İçeriği, Müfredat ve Kazanımlar } \\
\text { Alsstırmalar ve Sorular }\end{array}$ & $\begin{array}{l}8 \\
4\end{array}$ & $\begin{array}{l}33,333 \\
16,666\end{array}$ \\
\hline
\end{tabular}

Tablo 2'de ders kitaplarının aktif kullanımı teması altında pozitif ve negatif olacak şeklinde 2 kategori oluştuğu görülmektedir. Pozitif kategori altında matematik öğretmenlerinin yaklaşık \%38’i (f=9) ders kitaplarını konu içeriği, müfredat ve kazanımlar yönünden uygun bulurken, \%13'ü ( $\mathrm{f}=3$ ) alıştırmalar ve sorular yönünden uygun bulmaktadır. Negatif kategori altında ise matematik öğretmenlerinin yaklaşık \%33'ü (f=8) ders kitaplarını konu içeriği, müfredat ve kazanımlar yönünden, \%17'si (f=4) alıştırmalar ve sorular yönünden olumsuz görmektedir. Elde edilen bulgulara ilişkin örnek öğretmen görüşleri şöyledir;

Ö2. Kullanıyorum, alıştırmalar ve değerlendirmeler bölümünü etkin olarak kullanlyorum.

Ö10. Evet kullaniyorum. Derste konu ile ilgili soruları çözdürüyorum.

Ö13. Genellikle farklı kaynaklardaki soru ve alıştırmalardan yararlanıyorum.

Ö19. Aktif olarak kullaniyorum yalnız tek başına yeterli olmadığını düşünüyorum.

Ö22. Hayır, kullanmiyorum kitapta öğrencinin seviyesinde örnekler bulunmamaktadır.

Araştırmada üçüncü olarak ortaokul matematik öğretmenlerine dağıtılan ders kitaplarının ekstra kaynak kitap ihtiyacı sorulmuştur. Bu soruya verilen yanıtlardan elde edilen frekans, yüzde, kod, kategori ve temalara ilişkin bulgular Tablo 3 'te verilmiştir. 
Avrupa Bilim ve Teknoloji Dergisi

Tablo 3. Ekstra kaynak kitap ihtiyacl

\begin{tabular}{ccccc}
\hline Tema & Kategori & Kod & Frekans & $\%$ \\
\hline \multirow{3}{*}{ Ekstra kaynak } & İhtiyaç & Konu İçeriği, Müfredat ve Kazanımlar & 19 & $\mathbf{7 9 , 1 6 6}$ \\
& Durumu & Alıştırmalar ve Sorular & $\mathbf{3}$ & $\mathbf{1 2 , 5 0 0}$ \\
& & Anlaşılabilirlik & $\mathbf{2}$ & $\mathbf{8 , 3 3 3}$ \\
\hline
\end{tabular}

Tablo 3'te ders kitaplarına ekstra kaynak ihtiyacı teması altında ihtiyaç durumu olacak şeklinde 1 kategori oluştuğu görülmektedir. Bu kategori altında matematik öğretmenlerinin yaklaşık \%79'u ( $\mathrm{f}=19)$ ders kitaplarını konu içeriği, müfredat ve kazanımlar yönünden eksik bulurken, \%13’ü $(\mathrm{f}=3)$ alıştırmalar ve sorular yönünden eksik bulmaktadır. Ayrıca matematik öğretmenlerinin \%8'i $(\mathrm{f}=2)$ ders kitaplarının anlaşılabilirliğini düşük görmekte ve bu konular sebebiyle ekstra kaynağa ihtiyaç duymaktadır. Elde edilen bulgulara ilişkin örnek öğretmen görüşleri şöyledir;

Ö4. Evet, var çünkü sinav sistemi zor ve kitaplar yeterli değil.

Ö8. MEB' in ders kitabını ders esnasında hiç kullanmiyorum zaten sadece ödev olarak kullaniyorum çünkü MEB kitabında soru çözümlerinin anlaşılması eksik ve yardımcı kaynak kitaplarının kullanılmasına itiyor bizi.

Ö16. Vardır, çünkü öğrencinin daha farklı soru tarzları görmesi sağlanıyor tek tip soru çeşidinin yerine farklı sorular görmesi ögrencinin yorum gücünü arttırlyor.

Ö22. Evet, vardır sinav sistemine göre sinav sorularına bakıldı̆̆ında ders kitabından yararlanılarak çözülebilen sorulara pek rastlanmamaktadır.

Ö23. Ekstra kaynak kitabı kesinlikle ihtiyaç vardır, çünkü MEB soru yayınlıyor bu örnek sorular MEB kitabında olmadı̆g için ister istemez kaynak kitaplara ihtiyaç duymaktayız.

Araştırmada dördüncü olarak ortaokul matematik öğretmenlerine dağıtılan ders kitaplarının eğitim müfredatına uygunluğu sorulmuştur. Bu soruya verilen yanıtlardan elde edilen frekans, yüzde, kod, kategori ve temalara ilişkin bulgular Tablo 4 'te verilmiştir.

Tablo 4. Ders kitaplarınin eğitim müfredatına uygunluğu

\begin{tabular}{ccccc}
\hline Tema & Kategori & Kod & Frekans & $\%$ \\
\hline \multirow{3}{*}{ Müfredat } & \multirow{2}{*}{ Pozitif } & Uygun & $\mathbf{3}$ & $\mathbf{1 2 , 5 0 0}$ \\
& & Kısmen Uygun & $\mathbf{2}$ & $\mathbf{8 , 3 3 3}$ \\
\cline { 2 - 5 } & \multirow{2}{*}{ Negatif } & LGS & $\mathbf{1 2}$ & $\mathbf{5 0 , 0 0 0}$ \\
& & Konu İçeriği ve Kazanımlar & $\mathbf{5}$ & $\mathbf{2 0 . 8 3 3}$ \\
& & Alışırmalar ve Sorular & $\mathbf{2}$ & $\mathbf{8 , 3 3 3}$ \\
\hline
\end{tabular}

Tablo 4'te ders kitaplarının müfredatı teması altında pozitif ve negatif olacak şeklinde 2 kategori oluştuğu görülmektedir. Pozitif kategori altında matematik öğretmenlerinin yaklaşık \%13'ü (f=3) ders kitaplarını müfredata uygun bulurken, \%8'i (f=2) müfredat yönünden kısmen uygun bulmaktadır. Negatif kategori altında ise matematik öğretmenlerinin \%50'si ( $\mathrm{f}=12$ ) ders kitaplarını LGS yönünden, \%21’i $(\mathrm{f}=5)$ konu içeriği ve kazanımlar yönünden, \%8'i $(\mathrm{f}=2)$ alıştırmalar ve sorular yönünden müfredata uygun görmemektedir. Elde edilen bulgulara ilişkin örnek öğretmen görüşleri şöyledir;

Ö1. Müfredata uygun değildir. Matematikte üst bilişsel beceri gerektiren çok detaya bağll sorular bulunmaktadır. Öğrencilerin muhakeme gücü gerektiren sorular sinavda sorulmaktadır. MEB tarafindan dağttılan kitaplarda ise daha basit sorular sorulmaktadır. Ö2. Artık rutin olmayan problemlere doğru giriş yapıldĭ̆ından daha uygundur.

Ö8. Bence kesinlikle değil çünkü ögrrencilerin seviyeleri algılama düzeyleri göz ardı edilmektedir. Sorulan sorular ile anlatılan konular farkl zorluk seviyelerindedir.

Ö12. Klsmen uygundur.

Ö20. Şu anki uygulanan eğitim sistemi ve müfredat LGS' ye tam uygun olmasa da bir geçiş aşamasında olduğu görülmektedir.

Araştırmada son olarak ortaokul matematik öğretmenlerine dağıtılan ders kitaplarının nasıl geliştirilebileceğine yönelik fikir veya önerileri sorulmuştur. Bu soruya verilen yanitlardan elde edilen frekans, yüzde, kod, kategori ve temalara ilişkin bulgular Tablo 5 'te verilmiştir.

Tablo 5. Ders kitaplarının geliștirilmesine yönelik fikir ve öneriler

\begin{tabular}{ccccc}
\hline Tema & Kategori & Kod & Frekans & $\%$ \\
\hline \multirow{3}{*}{ Ders Kitaplarının } & & Alıștırmalar ve Sorular & 13 & $\mathbf{5 4 , 1 6 6}$ \\
Geliştirilmesi & Teknik ve & Konu İçeriği ve Kazanımlar & $\mathbf{5}$ & $\mathbf{2 0 , 8 3 3}$ \\
& İçerik & LGS & 4 & $\mathbf{1 6 , 6 6 6}$ \\
& & Anlaşılabilirlik & 2 & $\mathbf{8 , 3 3 3}$ \\
\hline
\end{tabular}


Tablo 5 'te ders kitaplarının geliştirilmesi teması altında teknik ve içerik anlamında bir kategori oluştuğu görülmektedir. Bu kategori altında matematik öğretmenlerinin yaklaşık \%54'ü ( $\mathrm{f}=13)$ ders kitaplarının alıştırmalar ve sorular açısından geliştirilmesi gerektiğini düşünürken, \%21’i (f=5) konu içeriği ve kazanımlar yönünden, \%17'si ( $\mathrm{f}=4)$ LGS sınavına dönük ve \%8’i (f=2) anlaşılabilirlik yönünden geliştirilmesi gerektiğine inanmaktadır. Elde edilen bulgulara ilişkin örnek öğretmen görüşleri şöyledir;

Ö8. Kitabın anlaşılır daha açıklamalı olması ögrrencilerin hep kaynak almasının önüne geçebilir. Bu ise konu anlatımına ve soru sayısının artırlmasına daha ayrıntılı bir şekilde çözümlerin verilmesine bağlıdır.

Ö13. Yeni sinav sistemine uygun yoruma dayalı farklı soru tipi ve ögrencilere eğlenceli aynı zamanda düşündürücü içeriklerin olması gerektiğini düsünüyorum.

Ö17. Müfredat öğrenci düzeyine göre tekrar düzenlenmeli, slnava yönelik olmayan beceri odakl bir sistem getirilmeli, ders kitapları MEB tarafindan yayınlanan örnek sorular paralelinde olmall, analitik düşünceyi geliştiren muhakeme becerisini ölçen düzeyde olmalıdır. Şu anki ders kitapları sadece bilgi ve kavrama düzeyindedir.

Ö18. Ders kitaplarında günlük hayat ile ilgili örneklere yer verilirken öğrenci seviyesine dikkat edilmelidir. Örnekler açık ve net bir şekilde verilmelidir. Öğrencinin ilgisini çekecek şekilde görseller ve örneklerle desteklenmelidir.

Ö21. Ders kitaplarının LGS sinavina uygun olarak tekrardan gözden geçirilmesi gerekmektedir.

\section{Tartışma, Sonuç ve Öneriler}

Bu çalışmada 5., 6., 7. ve 8. sınıflarda görev yapan matematik öğretmenlerinin matematik ders kitaplarıyla ilgili görüşleri incelendiğinde, ders kitaplarının LGS'ye uygunluğu noktasında öğretmenlerin yarıdan fazlasının uygun olmadığı görüşünde oldukları tespit edilmiştir. Bu görüşlerin nedenleri olarak matematik öğretmenleri soruların düzeyinin LGS ile uyumsuz olmasını, içeriğin sorunlu olmasını ve kitabın anlaşılabilirliğinin düşük olmasını göstermiştir. Bu sonuçların sebepleri matematik öğretmenlerinin ders kitapları ile LGS matematik soruları arasında bağ kurmada sorun yaşaması veya kitapların LGS ile paralel bir şekilde güncellenmemiş olması olabilir. Matematik öğretmenleri ders kitabını öğretim süreçlerinde aktif kullanım noktasında pozitif ve negatif olmak üzere iki farklı görüş bildirmişlerdir. Her iki görüş türündede aktif kullanımın veya kullanılmamasının sebepleri olarak konu içeriği, müfredat, kazanumlar, alıştırmalar ve sorular ön plana çıkmıştır. Matematik öğretmenlerinin yarısı ders kitabını öğretim süreölerinde aktif olarak kullandığını ifade ederken diğer yarısı aktif bir şekilde kullanmadığını belirtmiştir. Bu sonuçların sebepleri öğretmenlerin ders kitabını ödev veya uygulama kitabı olarak görmeleri olabilir. Matematik öğretmenlerinin hepsi ders kitabının dışında ekstra kaynağa ihtiyaç duyduğunu ve kullandığını ifade etmiştirler. Matematik öğretmenleri ekstra kaynağa ihtiyaç duyulmasının sebepleri olarak mevcut ders kitaplarını konu içeriği, müfredat, kazanımlar, alıştırmalar, sorular ve anlaşılabilirlik yönünden eksik görmeleridir. Bir diğer ifadeyle matematik öğretmenleri öğrencilerinin öğretim süreçlerinde ders kitaplarını birçok açıdan eksik görmüşler ve ekstra kaynağa başvurmayı tercih etmişlerdir. Bu sonuçların sebepleri öğretmenlerin öğretim ortamlarında veya ders kitaplarında yeteri kadar alıştırma yapamaması veya öğrencilerin farklı türde alıştırma veya problem türlerine ihtiyaç duyması olabilir. Matematik öğretmenlerinin yarıdan fazlası ders kitaplarını müfredat açısından da eksik bulmuştur. Bu görüşlerinin sebepleri araştırıldığında müfredatın LGS sınavı ile uyumsuzluğu, konu içeriği, kazanımlar, alıştırmalar ve soruların ön plana çıktığı görülmektedir. Bir diğer ifadeyle matematik öğretmenleri ders kitaplarını müfredatla teknik ve içerik açısından çokta uyumlu görememektedir. Bu sonuçların sebepleri matematik öğretmenlerinin ders kitaplarını içerik ve kazanım açısından müfredatla ilişkilendirmekte zorlanmaları veya kendi çerçevelerinden müfredatla beraber ders kitaplarını yorumlamaları olabilir. Ayrıca matematik öğretmenlerinin yapmıl oldukları dönem planları da bu noktada etkili olmuş olabilir. Matematik öğretmenlerinin dağıtılan ders kitaplarının nasıl geliştirilebileceğine yönelik fikir veya önerileri incelendiğinde öğretmenlerin genel anlamda teknik ve içerik yönünden öneride bulunduğu tespit edilmiştir. Matematik öğretmenleri ders kitaplarının alıştırmalar, sorular, konu içeriği, kazanımlar, LGS ve anlaşılabilirlik yönünden geliştirilmesini önermişlerdir. Bu sonuçların sebepleri matematik öğretmenlerinin içerik ve uygulama arasındaki eksiklikler nedeniyle sorun yaşaması, sistemsel olarak eksikliklerin olduğunu düşünmesi ve daha uygulanabilir bir öğretim materyali beklentileri olabilir. Alanyazın taraması yapıldığında araştırmanın bu bulguları ile örtüşen veya paralellik gösteren sonuçlara rastlamak mümkündür. Toprak (1993) çalışmasında ilkokul dördüncü ve beşinci sınıf matematik, fen bilgisi, sosyal bilgiler ve türkçe ders kitaplarının amaçlarına, öğrenci seviyesine ve fiziksel özelliklerine yönelik bir araştırma yapmıştır. Bu araştırmada ders kitaplarının genel olarak içerik, amaç veya öğrenci seviyesi açısından öğretim programına göre uygun olmadığı tespit edilmiştir. Doğan (1993) ise 1876-1918 yılları arasındaki okutulan ders kitaplarının sosyalleşme ve günlük yaşam ile ilişkisini araştırmış, kitapların içeriksel anlamda eksik olduğunu tespit etmiştir. Dayak (1998)'ın yapmış olduğu çalışmada matematik ders kitapları öğretmen ve öğrenci görüşleriyle incelenmiştir. Bu çalışmada ders kitaplarının öğrenci seviyesine uygun olmadığını, kitap içerisinde yer alan alıştırma kısmında soru tür ve sayı bakımından yetersiz kaldığını ve konu anlatımı bakımından bazı eksik ve yanlışların bulunduğu tespit edilmiştir. Semerci (2004) yapmış olduğu çalışmada ilköğretim türkçe ve matematik ders kitaplarını genel değerlendirme ölçeği geliştirerek ileride yapılacak olan çalışmalarda ders kitaplarının incelenmesi ve değerlendirilmesine yardımcı olmayı hedeflemiştir. Bu anlamda daha kaliteli kitapların üretilmesi yönünde katkı sağlanması hedeflenmiştir. Dane, Doğar ve Balkı (2004) matematik öğretmen adaylarının ilköğretim 7. sınıf matematik ders kitaplarını değerlendirmelerini incelemiş, öğretmen adaylarının ders kitabı seçiminde kendilerine ve öğrencilerine daha faydalı olacak kitapların nitelikleri ve seçimi konusunda bilgili olduğu sonucuna ulaşmışlardır. Çoban ve Erdoğan (2013) yapmış oldukları çalışmalarında dersin içeriği ile ilgili görülen problemleri ders kitabının dersin amacına uygun hazırlanmamış olmasına ve öğrenci seviyesine yeterince uygun olmayışına bağlamaktadırlar.

Çalışma kapsamında elde edilen bulgular ve sonuçlar çerçevesinde şu önerilerde bulunulabilir;

1. Matematik ders kitapları MEB'in belirlediği genel amaç, kazanım ve temel ilkelere paralel ve yeni sınav sistemine uygun olarak bu ve bunun gibi çalışmalar da dikkate alınarak güncellenebilir. 
2. Yeni sınav sisteminde sorulacak sorulara paralel bir şekilde MEB tarafindan hazırlanan ders kitabına ek olarak yeni nesil sorular içeren bir veya birkaç soru bankası öğrencilere dağıtılabilir. Böylece öğrencinin farklı kaynak kitaplara yönelmesi engellenebilir.

3. MEB tarafından öğretmenlere farklı türde alaştırma ve soruların bulunduğu ders içi uygulamalarda kullanılabilecek alıştırma kitapları dağıtılabilir.

4. Ders kitaplarını incelemek ve geliştirmek üzere üniversitelerde çalışan akademisyenlerden bir komisyon oluşturularak öğretmen görüşleriyle beraber ilgili kitaplar geliştirilebilir.

\section{Kaynakça}

Aydoğdu İskenderoğlu, T., Baki, A. (2011). İlköğretim 8. sınıf matematik ders kitabındaki soruların PISA matematik yeterlik düzeylerine göre sinıflandırılması. Eğitim ve Bilim Dergisi, 36(161), 287-301.

Büyüköztürk, Ş., Çakmak, E. K., Akgün, Ö. E., Karadeniz, Ş., \& Demirel, F. (2016). Bilimsel araştırma yöntemleri. Ankara: Pegem A Yayıncilik, 124-135.

Chmiliar, I. (2010). Multiple-case designs. In A. J. Mills, G. Eurepas \& E. Wiebe (Eds.), Encyclopedia of case study research (p. 582583). USA: SAGE Publications.

Creswell, J.W. (2007). Qualitative inquiry \& research design: Choosing among five approaches (2nd edition). USA: SAGE Publications.

Çoban, F. ve Erdoğan, A. (2013). Ortaokul öğretmenlerinin matematik uygulamaları dersinde karşılaştıkları sorunlar. Turkish Journal of Computer and Mathematics Education, 4(3), 242-258.

Dane, A., Doğar, Ç. ve Balkı, N. (2004). İlköğretim 7. sınıf matematik ders kitaplarının değerlendirilmesi. Erzincan Eğitim Fakültesi Dergisi, 6(2), 1-18.

Davey, L. (2009). The application of case study evaluations. Elementary Educatıon Online, 8(2), 1-10.

Dayak, E. (1998). İlköğretim 5. sınıf matematik ders kitaplarının eğitim-öğretime uygunluğunun değerlendirilmesi. Yayınlanmamış Yüksek Lisans Tezi, Marmara Üniversitesi, Eğitim Bilimleri Enstitüsü, İstanbul.

Delice, A. Aydın, E., Kardeş, D. (2009). Öğretmen adayı gözüyle matematik ders kitaplarında görsel öğelerin kullanımı. İstanbul Ticaret Üniversitesi Fen Bilimleri Dergisi, 8(16), 75-92.

Demirel, İ. N. (2018). Eğitim Teknolojisini Kullanma Yeterliliğine Dönük İfadeler ile Okuldaki Yardımcı Personelin Yeterliliğine Dönük İfadeler Hakkında Öğretmen Adaylarının Bakış Açıları. Turkish Studies. 13 (6), 53-68.

Doğan, N. (1993). Illk ve orta dereceli okul ders kitapları ve sosyalleşme (1876-1918). Ankara: Bağlam Yayınları.

Göze, N. (1999). Matematik zor değildir. Çağdaş Eğitim Dergisi, 256(1), 33-37.

Güven, S. (2010). İlköğretim hayat bilgisi dersi ders ve öğrenci çalışma kitaplarının öğretmen görüşlerine göre değerlendirilmesi. Eğitim ve Bilim Dergisi, 35(156), 84-95.

Milli Eğitim Bakanlı̆̆ı, [MEB]. (1997). 2479-2480 Sayll Tebliğler Dergisi. Ankara. Milli Eğitim Basımevi.

Merriam, S.B. (2013). Nitel araştırma: Desen ve uygulama için bir rehber (3. Baskıdan Çeviri, Çeviri Editörü: S. Turan). Ankara: Nobel Yayın Dağıtım.

Semerci, Ç. (2004). İlköğretim türkçe ve matematik ders kitaplarını genel değerlendirme ölçeği. Cumhuriyet Üniversitesi Sosyal Bilimler Dergisi, 28(1), 49-54.

Toprak, T. (1993). Illkokul ders kitaplarının öğretim programına uygunluğunun değerlendirilmesi (Adana ilinde bir araştırma). Yayınlanmış Yüksek Lisans Tezi, Ankara Üniversitesi Sosyal Bilimler Enstitüsü, Ankara. 
Ek 1. Matematik öğretmenlerine uygulanan yapılandırılmış görüşme formu soruları ve öğretmen cevapları

\section{Sizce Milli Eğitim Bakanlığı (MEB)'in dağıtmış olduğu ders kitapları LGS'ye uygun mudur?}

\section{Birinci soruya ilișkin öğretmen cevapları:}

Ö1. Yeni sınav sistemine kısmen uygundur. Fakat çok fazla eksiklikleri var. Daha çok etkinlik üzerine hazırlanan kitabımız sınav için yetersiz kalmaktadır. Sınavda zor ve muhakeme gücü gerektiren sorular sorulmaktadır. Kitabımızdaki sorular LGS sınavi için basit kalmaktadır. Önceki TEOG sınavına yeterli iken şimdiki LGS sınavı için kesinlikle yetersiz.

Ö2. Verilen kitaplarda örneklerin az olduğunu düşüncesindeyim. Bol örnek ve çözümlü sorular olmalıdır.

Ö3. Kitapların yeni sınav sistemine uygun olarak hazırlandı̆̆ını düşünüyorum.

Ö4. Uygun olduğu gibi olmadı̆̆ tarafları da vardır. Mesela bazl yerlerde teorik kalıyor.

Ö5. Ders kitapları içerik, kazanım ve soru bakımından LGS sınav sistemi için uygundur.

Ö6. MEB'in dă̆ıttı̆̆ kitaplar bana göre LGS için \%100 uygun değildir. Çünkü sinavda sorgulanan birey özellikleri daha yaratıcı olma, analitik beceri sahibi ve ezberden uzak bir modeldir ancak verilen kitapların bu konuda uygun olduğunu düşünmüyorum.

Ö7. Daha uygun hale getirilebilir özellikle teorik kısımlar.

Ö8. Hayır, uygun değildir. Çünkü öğrencilerin tamamının anlama düzeyine hitap etmiyor Ayrıca soru çözümlerinin açıklama kısmının yeterli olmamasl da zorlanmalarina neden oluyor.

Ö9. Yeterli olduğunu düşünmüyorum genelde konunun içeriğine göre eksik kalıp sorular oluyor ve genelde yeni sisteme uygun olmayan soru tarzlarl içeriyor.

Ö10. Uygun değildir. Çünkü LGS'de daha çok yorum ve bilgi ă̆ırlık iken ders kitabı direkt bilgiye dayalıdır ve klsa sorular çoğunluktadır.

Ö11. Kesinlikle LGS sınav formatına uygun bulmuyorum. LGS'de çıkacak soru örneklerine bakıldı̆̆ında öğrenciye analitik düşünmeyi hedefleyen sorular sorulmaktadır. Kitapta bulunan sorular eski düşünme tarzının devamı şeklindedir.

Ö12. MEB' in kitabı piyasadaki mevcut test kitaplarından daha açıklayıcı ve kapsayıcıdır. Fakat yılsonunda yapılan genel sınav soruları maalesef kitabın soru tarzının dışındadır. Bu da ögrencileri özel yayınların çıkardı̆̆ kitaplara yöneltmektedir.

Ö13. Yeteri kadar uygun değildir. Değişim sınav sisteminde olduğu için zamanla kitap içerikleri de uygun hale gelecektir.

Ö14. Hayır, uygun değildir.

Ö15. Hayır, uygun değildir. MEB kitabı sadece bütün ögrenciler için ortak bir kaynaktır. LGS sistemi ise daha üst düzey öğrenciler için yapılan bir sılnav sistemidir.

Ö16. Uygun değildir. Çocuğa ezberden çok yorumlama yapabileceği soru tarzları sorulmuyor. Öğrenci 8. sinıfa geldiğinde bu tarz sorularl gördügünde dersten soğuyor basit düzeyden zor düzeye doğru sinıf seviyesinde bu tarz sorular etkinleştirilmelidir.

Ö17. Ders kitabında bilgi ve kavrama düzeyinde içerik ve sorular var. Yeni sinav sistemi ise mantı, muhakeme ve analitik beceri isteyen sorulardır. Bu nedenle uygun değildir.

Ö18. Uygundur.

Ö19. Önceki yıllar dă̆ıtılan ders kitaplarına oranla uygunluğunun arttırıldı̆̆ı söylenebilir. Uygun olması için üzerinde çalışılması gerektiği kanaatindeyim.

Ö20. Uygun değildir ders kitapları daha çok ezbere yönelik iken LGS Sınavı ise neden sonuç ilişkisi kurabilme, verilmeyeni algllayabilme, problem çözme, analiz yapma, eleştirel düşünme ve bilimsel süreç becerilerini kullanabilme gibi üst düzey yeterlilik gerektirecek sorulardan oluşmaktadir.

Ö21. LGS soruları genellikle seçici ve uzun anlatım, yorum, tablo içeren sorulardan oluşmaktadır. Ders kitapları ise daha çok ezbere yönelik sorulardan oluşmaktadır.

Ö22. Uygun değildir. Kitap anlaşılması zor örneklerden ve deneylerden oluşmaktadır.

Ö23. Hayır değildir. Çünkü MEB'in yayınladı̆̆ı kitaplar ezbere yönelik hazırlanmaktadır. Fakat LGS'de çıkan sorular yoruma dayalıdır.

Ö24. MEB'in dă̆ıttı̆̆ kitaplar kesinlikle LGS'ye uyumlu değildir. Çünkü yeni sınav sistemi yoruma dayalı sorulardan oluşmakta ve bu sorulara maalesef $M E B^{\prime}$ in dă̆lttı̆̆ hiçbir kitapta değinilmemiştir. Sadece konu sonlarında çok az soru vermekle yetinmişler ve bunların içinde de kesinlikle LGS ile alakalı olan hiçbir soru bulunmamaktadır.

\section{MEB'in dağıtmış olduğu ders kitaplarını aktif bir şekilde kullanıyor musunuz?}

\section{İkinci soruya ilișkin öğretmen cevapları:}

Ö1. Aktif olarak kullanmıyorum. Yetersiz kalıyor, sadece kazanımlar için bakıyorum.

Ö2. Kullanıyorum, alıştırmalar ve değerlendirmeler bölümünü etkin olarak kullanıyorum.

Ö3. O4. Ö5. Ö6. Evet.

Ö7. Tam anlamiyla kullanmiyorum.

Ö8. Hayır, ders içeriğinin az ve açıklama kısmının yetersiz olması yardımcı kaynaklar kullanmama neden olmaktadır.

Ö9. Bazı konularda kullanıyorum. Ünite sonu değerlendirme sorularını derste mutlaka çözdürüyorum.

Ö10. Evet kullaniyorum. Derste konu ile ilgili soruları çözdürüyorum.

Ö11. Evet, haftalık programın son saatlerinde her sinıf düzeyinde aktif olarak kullanıyorum.

Ö12. Aktif olarak kullanıyorum.

Ö13. Genellikle farklı kaynaklardaki soru ve alıştırmalardan yararlanıyorum. 
Ö14. Kullanmıyorum kitapların içerikleri kazanımların çok altında yer alıyor.

Ö15. Aktif olarak kullanmiyorum. Sadece bazen alıştırma ve etkinlikleri uyguluyorum. Ev ödevi olarak veriyorum.

Ö16. Genellikle konu bitiminde içindeki alışstrma ve soruları çözmek için kullanıyorum. Derste aktif bir şekilde kullanmıyorum.

Ö17. Sadece ders kitabındaki kazanım sorularını derste çözüyorum aktif olarak kullanmıyorum.

Ö18. Evet, aktif olarak kullaniyorum.

Ö19. Aktif olarak kullaniyorum yalnız tek başına yeterli olmadığını düşünüyorum.

Ö20. Evet, müfredat programı takip açısından kullanmaktayım.

Ö21. Müfredatı takip açısından kullanıyorum.

Ö22. Hayır, kullanmiyorum kitapta ögrencinin seviyesinde örnekler bulunmamaktadır.

Ö23. Hayır, kullanmıyorum, çünkü fayda sağlayacă̆ını düsünmüyorum MEB' in kitapların yetersiz buluyorum.

Ö24. Kesinlikle MEB' in kitaplarını hiçbir ögrretmen şu anda kullanmıyor özellikle 8 sinıf öğretmenleri.

\section{3. Öğretim sürecinde MEB'in dağıtmış olduğu kaynak kitaplarına ek olarak kaynak kitap ihtiyacı duyuyor musunuz?}

\section{Ücüncü soruya ilișkin öğretmen cevapları:}

Ö1. Ekstra kaynak kitabı ihtiyaç vardır. Yeteri kadar soru bulunmamaktadır. Sinava uygun değildir. Matematik doğası gereği zordur ve anlaşılması zordur bu zorlu ortadan kaldirabilmek için örnek çeşitleri uzaklaş̧tırlarak arttırılmalıdır. Sinavda beyin firtınası gerektiren sorular sorulmaktadır, bu tür sorular arttırlmalıdır.

Ö2. Elbette ki ekstra kaynak demek farklı sorular ve farkl çözüm yolları demektir.

Ö3. Ekstra kaynak kitabı ihtiyaç vardır. Konuların daha iyi kavrama bilmesi öğrenilenlerin kalıcılığının sağlanabilmesi için çok fazla örnek allştırmanin yapılması gerekir. Bu eksikliğin kapatılması için yardımcı kaynak kitap gereklidir.

Ö4. Evet, var çünkü slnav sistemi zor ve kitaplar yeterli değil.

Ö5. Evet, sinav sistemi hızlı bir soru çözümünü gerektirmekte ezberden ziyade bilgiyi kullanabileceği uzun sorulardan oluşmakta bunun olabilmesi için öğrencinin çok fazla alıştırma yapmast gerekir.

Ö6. Ekstra kaynak kitabı ihtiyaç vardır, çünkü soru çeşitliliği bakımından farklı kaynaklara ihtiyaç olur.

Ö7. Kesinlikle evet çünkü sinavlarda çıkan soru tipleri ile okullarda okutulan kitapların soru uyuşmuyor.

Ö8. MEB' in ders kitabını ders esnasında hiç kullanmiyorum zaten sadece ödev olarak kullanlyorum çünkü MEB kitabında soru çözümlerinin anlaşılması eksik ve yardımcı kaynak kitaplarının kullanılmasına itiyor bizi.

Ö9. Kesinlikle ekstra kaynak gerekli ders kitabı etkinlik ve soru tarzları konusunda yetersiz düşündürücü ve dikkat gerektiren yeni sinav sistemine uygun sorular içermediği için ekstra kaynak kitap kullanmak gerekiyor. Ayrıca sadece ders konu anlatımı veriyor çalışma kitabı olmadı̆̆ için çok az soru var içerisinde.

Ö10. Soru çeşidi açısından ihtiyaç duyulabilir.

Ö11. Matematik dersi konu kapsamı olarak her kitapta bilgiye çabuk erişilebilir, fakat soru tarzı olarak geniş bir kapsama alanı vardır. Bu sebeple birçok kaynak kitabı kullanımı farklı soru tarzına hakim olmayı arttırır.

Ö12. Soru adedi bakımindan MEB' in kitabl yetersizdir.

Ö13. Kaynak kitap olmalı eksik ya da hatırlatma amacı ile bilgiler yer almayı öğrencilerin konuyu bildikleri varsaylmaktadır. Ayrıca çok fazla soru tipi yer almasindan dolayı farklı kaynaklardan yararlanılmalıdır.

Ö14. İhtiyaç vardır, çünkü yeterli soru çözümü MEB' in kitabı ile mümkün değildir.

Ö15. Kesinlikle ihtiyaç vardır. Matematik öğretim programı çok yoğun olduğu için öğretmenlerimiz programı yetiştirme telaşındadır aynı zamanda öğrencilerin her türlü soru çeşidini görmesi açısından birden çok kaynağa ihtiyaç vardır.

Ö16. Vardır, çünkü ögrencinin daha farklı soru tarzları görmesi sağlanıyor tek tip soru çeşidinin yerine farkl sorular görmesi ögrencinin yorum gücünü arttırtyor.

Ö17. Uygulanan sinav sistemi çok soru çözmeyi gerek tip yorum gücü yüksek analitik düşüncesi olan ögrencileri istemektedir. Ders kitabinda ona yönelik sorular yoktur. Bu nedenle kaynak kitaba gerek vardır.

Ö18. Bazen ihtiyaç duyuyorum. Ders kitabında yeterince kapsaylcı sorulara yer verilmiyor.

Ö19. Kesinlikle kullanıyorum. Nedenine gelecek olursak konu anlatım kısmının sinırlllğ̆ı ve örnek soru konusundaki yetersizlik göz önüne alınırsa ek kaynak kullanmak kaçınılmazdır.

Ö20. Evet, LGS sinavina hazırlanan ögrenciler daha çok pratik yapması açısından farklı kaynaklar değişik soru tipleri çözmeleri açısından ekstradan kitaplar tercih edilmektedir.

Ö21. Evet, LGS sinavi saylsal mantık gerektiren sorulardan oluştuğu için öğrencileri pratik yapabilmeleri için farklı kaynaklardan soru çözmeleri için ekstra kaynak tercih edilmelidir.

Ö22. Evet, vardır sinav sistemine göre sinav sorularına bakıldı̆̆ında ders kitabından yararlanılarak çözülebilen sorulara pek rastlanmamaktadır.

Ö23. Ekstra kaynak kitabı kesinlikle ihtiyaç vardır, çünkü MEB soru yayınlıyor bu örnek sorular MEB kitabında olmadığı için ister istemez kaynak kitaplara ihtiyaç duymaktaylz.

Ö24. Tabi ki ihtiyaç vardır çünkü MEB' in kitaplarına paralel ders işlersek öğrenciler sinava hazırlanamaz, daha doğrusu yanlış hazırlanmış olur.

\section{Sizce MEB'in dağıtmış olduğu ders kitapları müfredata uygun mudur?}

\section{Dördüncü soruya ilisskin öğretmen cevapları:}


Ö1. LGS'ye uygun değildir. Matematikte üst bilişsel beceri gerektiren çok detaya bağll sorular bulunmaktadır. Öğrencilerin muhakeme gücü gerektiren sorular sinavda sorulmaktadır. MEB tarafindan dağıtılan kitaplarda ise daha basit sorular sorulmaktadır. Ö2. Artık rutin olmayan problemlere doğru giriş yapıldiğından daha uygundur.

Ö3. Hayır, kitaplar LGS' ye uygun değildir. LGS soruları uzun sorulardan oluşmaktadır. Bu ögrencinin verilen bilgileri nasıl kullanacağı noktasında belirsizliğe sebep olmaktadır. Uygulanan eğitim sistemi bilgi verip işlem yapacağı kavrama basamağında kalan sorulardan oluşmaktadir.

Ö4. Hayır, uygun değildir.

Ö5. Sinfflarda uygulanan sistem bilgi ve kavrama düzeyinde kallyor. LGS sinav sistemine uygun değildir.

Ö6. Kesinlikle hayır, verilen eğitim öğretim ile uygulanan daha doğrusu ölçüm testleri farklıdır.

Ö7. Fikrim yok.

Ö8. Bence kesinlikle değil çünkü ögrencilerin seviyeleri algılama düzeyleri göz ardı edilmektedir. Sorulan sorular ile anlatılan konular farkl zorluk seviyelerindedir.

Ö9. Hayır, uygun değildir. Ancak biz kendi çabalarımızla yeni sisteme uydurmaya çalışıyoruz.

Ö10. Bence değil, çünkü $L G S$ ' de okuma-anlamaya dayalı sorular çoğunlukla soruluyor, ancak şu anki eğitim sistemi bilgi depolamaya yöneliktir.

Ö11. Kesinlikle değil, müfredat kazanımları saf bilgiyi öğrenciye vermeye teorik olarak ders işlemeye planlanmıştır. LGS daha çok üst düzey düşünmeyi, bilgiyi yorumlamayı hedefliyor.

Ö12. Klsmen uygundur.

Ö13. Sistemin yeni değişmesi ögrencilerde olumsuz yönde etki yaratmakla beraber eğitim sistemine uygun değildir. Eğitim sistemi ezberci iken LGS daha çok yorum ve düşündürmeyi ön plana almaktadır.

Ö14. LGS bir defa uygulandl, soru ve kazanımlar öğrenci seviyelerinin çok üstündeydi. LGS eğitim sistemine uygun değildir.

Ö15. Uygun değildir, fakat öğretmen olarak elimizden gelen çabayı gösteriyoruz. Zaten sistem olarak LGS her öğrencinin nitelikli bir okula gitmesi için oluşturulmamıştır. LGS sadece yüzde onluk bir klsmı karşılamaktadır.

Ö16. Bence uygun değildir. Bu kadar zorlanması da uygun değil, çünkü bu konu disiplinler arası yaklaşıma terstir. Sadece bir dersi zorlamak mantıklı değil bizim eğitim sistemimizin LGS ye uygun olması için ögrrencinin birinci sinıftan itibaren düşündürücü sorular çözmesi gerekmektedir.

Ö17. Eğitim sistemimizin mi LGS ye uygun değil yoksa LGS sistemi mi eğitim sistemimize uygun değil arası bir tartı̧ma konusudur.

Lakin birbiriyle örtüşmedikleri kesin. Bunları uygun hale getirecek kişiler öğretmenlerdir.

Ö18. Evet uygundur.

Ö19. Maalesef uygun değil. Aslinda şöyle de söyleyebiliriz ki; LGS eğitim sistemine uygun değildir.

Ö20. Şu anki uygulanan eğitim sistemi LGS' ye tam uygun olmasa da bir geçiş aşamasinda olduğu görülmektedir.

Ö21. Hayır, çünkü LGS sinavı daha çok mantık gerektirirken günümüzdeki eğitim sistemi daha çok ezbere yöneliktir.

Ö22. Uygun değildir. Öğrencilerin LGS' ye hazırlanmast için test çözmeleri test çözme tekniklerini ögrenmeleri gerekmektedir. Test çözmekten daha çok bilgiyi ezberleterek ögretmekteyiz.

Ö23. Şu anki eğitim sistemi yeni sınav sistemi LGS' ye uygun değildir. Biz elimizden geldiği kadar ayarlamaya çalışıoruz.

Ö24. Hayır, uygun değildir. Çünkü eğitim sistemi ezbere dayalıdır. Sinav sistemi ise buna paralel değildir.

\section{MEB'in dağıtmış olduğu ders kitaplarının geliştirilmesine yönelik fikir ve önerileriniz nelerdir?}

\section{Beșinci soruya iliskin öğretmen cevapları:}

Ö1. MEB tarafindan dağıtılan kitaplar kazanımlara göre hazırlanmış genellikle basit sorular içermektedir. Bazı etkinliklerde kullanılan araç ve gereçleri bulmak zor olabiliyor. Böyle hazırlanan bir kitap için okullarda bu etkinliği yapabilecek matematik sinıfları bulunmalıdır. Öğrencilerin muhakeme gücünü ve yaratıcı düşüncelerini gelişstirebilecekleri etkinlikler bulunmalı ya da bunlara uygun sorular hazırlanmalıdir.

Ö2. Ders kitaplarında test bölümü arttırllmalı projeye ve performansa yönelik bölümler oluşturulmalıdır.

Ö3. MEB kitaplarının konu anlatımı güzel ama soru açısından yeterli değildir. Soru bankası şeklinde bir yardımcı kaynak kitap dağıtılabilir.

Ö4. Örneklerinin çoğaltıllp soru bankasının da çıkarılması gerekmektedir.

Ö5. Ders kitapları kazanımlar için güzel hazırlanmış ama alıştırmalar yeterli değildir. Bunun yanında soru bankası şeklinde ekstra kaynak kitap verilebilir.

Ö6. MEB tarafindan dağıtılan ders kitapları kesinlikle güncellenmiyor. Bazı yerlerde içerik içerisinde hata yapılan yerler var, müfredatın güncellenmesi şarttır.

Ö7. Dağıtılan kitaplar öğrencinin bilgi ve becerisine yönelik hazırlanmasl gerektiğini dü̈sünüyorum.

Ö8. Kitabın anlaşıllı daha açıklamalı olması ögrencilerin hep kaynak almasının önüne geçebilir. Bu ise konu anlatımına ve soru sayısının artırlmasına daha ayrıntılı bir şekilde çözümlerin verilmesine bağlıdır.

Ö9. Keşke eğitim sistemlerini değiştirme kararı verdiklerinde önce dağıttıkları kitaplarda o değişiklikleri yapıp sonra sistemi değiş̧tirseler. Önce sistemi değişip sonra kitapları o sisteme göre değiştirmek zaman alyyor. Bu da bize zaman kaybettiriyor sistem değişikliğini önce kendi kitaplarında gerçekleştirip soru örneklerini ona göre hazırlayıp sonra uygulamaya geçmeliler. Çalışma kitabı mutlaka dă̆ıtılmalı soru yoğunluğu fazla olan bir kaynak daha matematik için dağıtılmalıdır.

Ö10. Öğrencileri düşündürecek tarzda sorular sorulmalıdır. Yorum ve bilgi içerikli sorular sorulmalıdır. Öğrenciyi zorlayacak sorular sorulmalıdir. 


\section{Avrupa Bilim ve Teknoloji Dergisi}

Ö11. Bu sene yapılan değişiklikle matematik tarihi bölümleri öğrencilerin ilgisini çekiyor. Bu olumlu bir katkı fakat birçok sorunun yanlış yazılması hataların ölçme-değerlendirme bölümlerinde olması yeni baskıların olmasını gerektirmektedir.

Ö12. Yılsonunda yapılan sinavlardaki soru tarzı MEB kitabını temel alarak yapılmalıdır.

Ö13. Yeni sınav sistemine uygun yoruma dayalı farklı soru tipi ve öğrencilere ĕglenceli aynı zamanda düşündürücü içeriklerin olması gerektiğini düşünüyorum.

Ö14. Daha fazla soru çözümüne yer verilmelidir.

Ö15. Daha çok sorunun olmasını bekliyoruz. Her etkinlik sınıfta yapılamıyor kaliteli, özgün örnekler olmalı ve etkinlikler nitelikli olmalidir.

Ö16. Dă̆ıtılan kitaplar daha çok ögrenciye ve öğretmene hitap etmelidir. Sadece ders kitabı çıkardık diye çıkarılmamalı sordukları sorulara benzer sorular sorulmalı ve bu konular anlatılmalıdır. Birçok kitabın içi boş biraz daha özenli ve dikkatli kitaplar hazırlanmalı çocuklar kitaplara özendirilmelidir. Öğrenci kendisine hitap etmediği için dışarıdan farklı kaynak almak zorunda kallyor, bunun önüne geçilmelidir.

Ö17. Müfredat ögrenci düzeyine göre tekrar düzenlenmeli, slnava yönelik olmayan beceri odaklı bir sistem getirilmeli, ders kitapları MEB tarafindan yayınlanan örnek sorular paralelinde olmall, analitik düşünceyi geliştiren muhakeme becerisini ölçen düzeyde olmalıdır. Şu anki ders kitapları sadece bilgi ve kavrama düzeyindedir.

Ö18. Ders kitaplarında günlük hayat ile ilgili örneklere yer verilirken ögrenci seviyesine dikkat edilmelidir. Örnekler açık ve net bir şekilde verilmelidir. Öğrencinin ilgisini çekecek şekilde görseller ve örneklerle desteklenmelidir.

Ö19. Ĕ̈itim sisteminin sınava uygun olamadığını görüyoruz ve ders kitaplarının da yeterli olmadı̆̆ını da biliyoruz. Bunun en önemli kanıtlardan biri hemen hemen her öğretmenin tek başına ders kitaplarını kaynak olarak kullanmamasıdır.

Ö20. Ders kitapları biraz daha saylsal mantık gerektiren eleştirel düşünmeyi sağlayan analiz yapma gibi bol pratik gerektiren aşamalardan olmalıdır.

Ö21. Ders kitaplarının LGS sınavına uygun olarak tekrardan gözden geçirilmesi gerekmektedir.

Ö22. Ders kitaplarının test kitapları gibi düzenlenmesi ve daha çok soru içerecek biçimde hazırlanması daha uygun olacaktır. Çünkü sınav sistemi düşünüldüğ̈̈nde öğrencilerin soru çözmeleri gerekmektedir.

Ö23. $M E B^{\prime}$ in hazırladiğ kitaplar kesinlikle $M E B^{\prime}$ de çalışan öğretmenlerden oluşan bir ekip tarafindan hazırlanmalıdır. LGS sınavında sorulacak sorular MEB' de çalışan ögretmenler tarafindan hazırlanırsa daha iyi olur.

Ö24. MEB yıllardır bu formatta kitaplar yayınlıyor sınav sistemi ile oynayıp değiştirdiği kadar kitaplarla da oynar ve değiştirirse belki doğru formatı bulabilir. Issi uzmanlarına bırakmaları gerekmektedir. 